\title{
Efficacy in the treatment of depressive disorders
}

\author{
Taysa Leite de Aquino (iD), Jaiany Rodrigues Libório (iD), Ana Luiza Menezes Santana Bezerra (D), \\ Giovana Macêdo Egídio Cavalcante (D), Dara Fernanda Brito Duarte ${ }^{(D)}$, \\ Ana Luíza de Aguiar Rocha Martin ${ }^{\circledR}$, Juliane dos Anjos de Paula ${ }^{(D)}$, Modesto Leite Rolim Neto
}

School of Medicine of Juazeiro do Norte - FMJ/Estácio, Juazeiro do Norte, Ceará, Brazil

\section{$凶$}

Modesto Leite Rolim Neto

School of Medicine of Juazeiro do Norte - FMJ/Estácio, Juazeiro do Norte, Ceará, Brazil.

modesto.neto@ufca.edu.br

Edited by:

Juliana Ramos de Andrade
Keywords:

New Treatment

Pharmacological

Depressive Disorder

\begin{abstract}
Introduction

Depression, being the most disabling disease in the world and presenting high morbidity and mortality, requires an effective treatment to ensure the maintenance of the patients' quality of life. About a third of patients do not respond adequately to antidepressant treatment. New pharmacological therapies are being approached in order to reduce the unfavorable outcomes resulting from this pathology.

Objective

To develop a systematic review of the literature on the new possibilities of pharmacological treatments for depression in the last four years.

Method

A systematic review was carried out following the PRISMA protocol (Preferred Reporting Items for Systematic Reviews and Meta-Analysis). We have included studies on the effectiveness of new pharmacological therapies in patients with major depressive disorder and treatment-resistant depression.

Results

In the treatment of the major depressive disorder (MDD), the use of brexpiprazole $1 \mathrm{mg} /$ day in addition to the usual antidepressant treatment (ADT) resulted in significant improvement in the main symptoms. Already referring to treatments for treatment-resistant depression (TRD): nasal esketamine proved beneficial in the short term, intravenous (IV) ketamine also appears as an effective therapy.

\section{Conclusion}

The use of brexpiprazole $1 \mathrm{mg} /$ day associated with an antidepressant, and the use of lactobacilli represent a new option for those with MDD. In addition, both ketamine, riluzole, and cariprazine appear as new hopes for those who have not yet achieved remission of the depressive disorder with the use of more than two antidepressants.
\end{abstract}




\section{Introduction}

The World Health Organization (WHO) already predicted, according to the pace of diagnosis and the characteristics of the disease, that in 2020 depression would become the most disabling disease in the world. Currently, depression is responsible for the reduction of up to ten years of life expectancy, is the main cause of disability, has high rates of morbidity and mortality, being responsible, therefore, for an extremely negative direct impact on the quality of life of more than 322 million of people around the world, confirming and exceeding WHO estimates. ${ }^{1.3}$

Facing a disease with unfavorable outcomes, treatment becomes essential to maintain the patients' quality of life. However, a third of individuals diagnosed with depression do not respond adequately to the first-choice treatments, including monoamine reuptake. ${ }^{4}$ In addition, these drugs take between three to seven weeks to start their antidepressant effects and up to 12 weeks to achieve maximum effect, as well having side effects in most users. In many situations, the combination of two or more of these drugs is not able to cease the patient's depressive symptoms, raising him to the diagnosis of treatment-resistant depression. ${ }^{1,5}$ In this sense, the need for more effective treatments, with a faster onset of action, better dosage, and fewer side effects has increased in recent years and new therapeutic approaches for depressed patients have emerged aiming to reduce the unfavorable outcomes resulting from this pathology.

However, the proposed therapies face difficulties due to the long time spent and the high costs for the development of a new drug. This path takes, on average, 14 years. However, with the study of new approaches to products that are already consolidated in the market and the reuse of drugs, this time reduces to less than half, around six years. ${ }^{6}$ Currently, many drugs are in the process of analysis and face difficulties such as the short observation time, the need for further studies related to the neurobiological mechanisms involved in the pharmacodynamics of the proposed drugs; or even the difficulties with the selection of the requirements for the study, which is often small and restricted to a region. However, both a long-term analysis and an understanding of the mechanism of action of the drug associated with the physiological processes of depression and the heterogeneity of the study group are extremely useful to understand and attest to the effectiveness of new therapies. ${ }^{4,5}$

Given this situation and taking into account that 20 to $30 \%$ of individuals with major depressive disorder (MDD) develop treatment-resistant depression $(T R D)^{6}$, we aim to develop a systematic review of the literature regarding the new possibilities of pharmacological treatments for depression based on the acronym PICO: P: study population - people with depressive disorder according to DSM V 296.21, 296.22, 296.23 and 296.24; I: intervention - to demonstrate the effectiveness of new pharmacological therapies for depression; C: control - individuals with MDD and TRD; O: outcome - new pharmacological approaches to depressive disorders.

This question has had a greater impact in recent years due to the need for new pharmacological treatments since the number of patients with TRD and MDD who respond inadequately to conventional treatment is increasing. Thus, this study aims to formulate a systematic review of the literature regarding new pharmacological treatments for depression.

\section{Method}

A systematic review was carried out, following the PRISMA protocol (Preferred Reporting Items for Systematic Reviews and Meta-Analysis).

\section{Inclusion criteria}

The inclusion criteria were studies published in English, Portuguese and Spanish, suitability for this review, methodological rigor applied, and full text available for free. Review articles, as well as comments on literature, editorials, communications, and letters to the editor, were excluded. We had no restrictions related to the study design, methodological quality, or language. The problem with the language was solved through a reasonable degree of comparability, which allowed us to systematically analyze the selected evidence, its critical evaluation process, and its success in including relevant studies in other languages.

We classified assessments according to their level of inclusion of studies in other languages. Reviews that excluded non-English studies with an explicit justification in the research question or research objectives were categorized as justified by R1 (that is, justified in English), while those that excluded non-English studies without justification were categorized as restricted to RR1 (that is, languages that are not restricted to English). Reviews that did not explicitly exclude studies that were not in English were categorized as RR1-open unless they successively included studies that were not in English, in which case they were RR1-inclusive. Finally, revisions that did not declare language criteria were considered to be RR1-open. 


\section{Literature search and article selection}

To search for the studies, the following databases were used: PubMed, LILACS and Science Direct data, from 2018 to $2021 \mathrm{c}$ with the descriptors MeSH and DeSC: "Pharmacological Treatment" AND/OR "Tratamento Farmacológico", "New Treatments" AND/OR "Novos Tratamentos", "Depressive Disorder" AND/OR "Transtorno Depressivo".

Data extraction and methodological quality assessment One researcher (MLRN) extracted the data, and another verified the extraction. Two researchers (ALARM and JAP) independently assessed the methodological quality of systematic reviews using the AMSTAR tool and qualitative studies using the CASP checklist (Critical Appraisal Skills Program - CASP, 2020). One researcher (ALARM) assessed the quality of cross-sectional studies using the JBI Prevalence or the JBI Cross-sectional analytical checklist and longitudinal studies using the JBI Cohort checklist (Johanna Briggs Institute).

\section{Data presentation and analysis}

We describe the interventions and results based on the information provided in the studies. When studies showed results of new pharmacological therapeutic approaches to depressive disorders in numbers without numbers, we extracted them using online software. $^{7}$

\section{Data presentation and analysis}

We summarize the results narratively. We describe the interventions and results based on the information provided in the studies. When the studies showed results regarding new pharmacological therapeutic approaches for depressive disorders in the last four years, we extracted them using online software. ${ }^{7}$ We classify the certainty of the evidence using the GRADE approach (Grading of Recommendations, Assessment, Development and Evaluations).

\section{Results}

The data were collected independently by three reviewers (ALARM, JAP, ALMSB, and MLRN). If there was disagreement between the evaluators on the inclusion and exclusion criteria, a specific discussion was made about the article in question until a final consensus. The necessary information was collected from published articles (Figure 1).

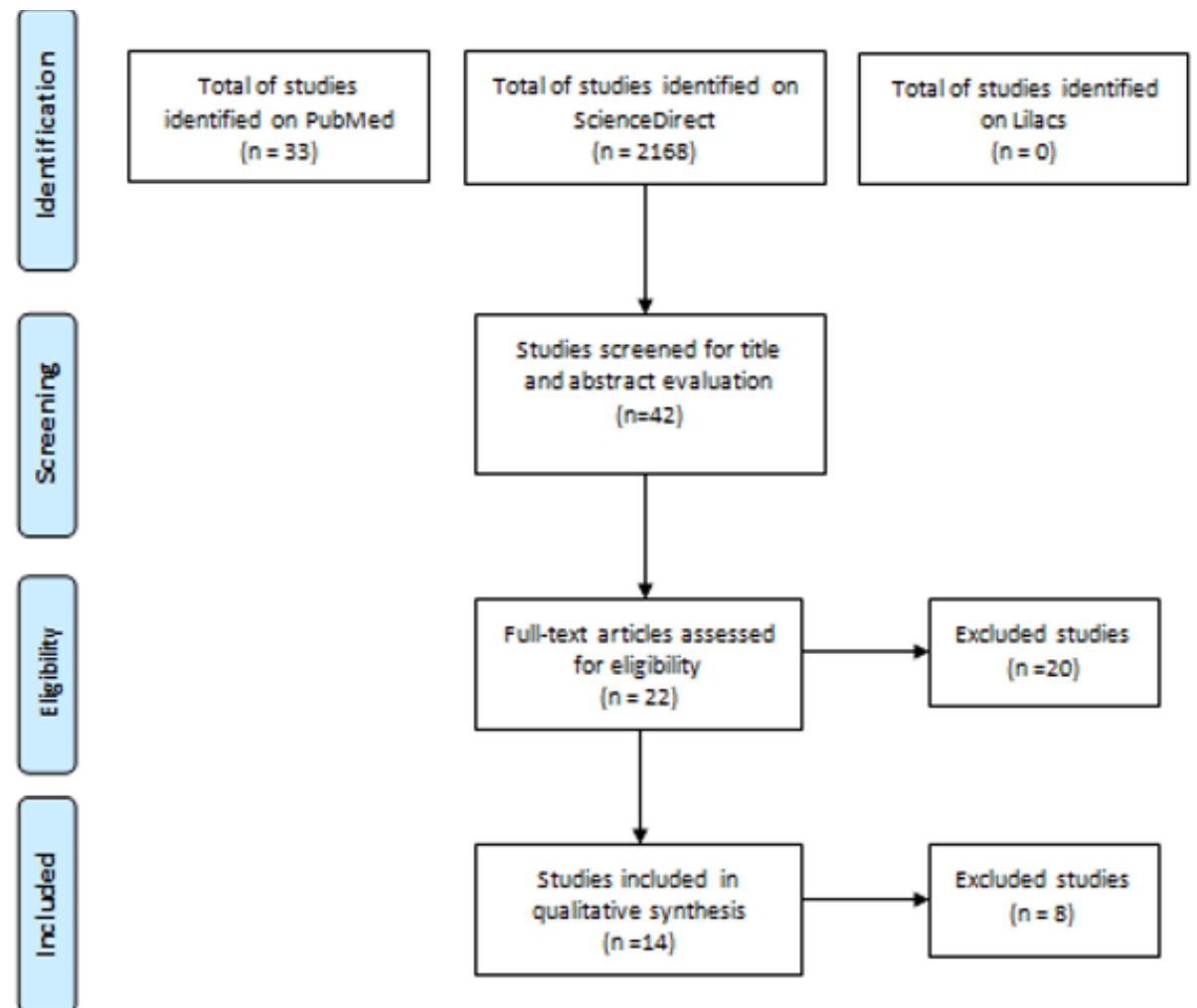

Figure 1. Bibliographic research flowchart 
A total of 2,201 articles were found. Five independent TRD; Costi et. al. ${ }^{10}$ - a study about lithium preventing researchers evaluated the titles and abstracts of the severe depression after cessation of ketamine use; articles, 42 studies were pre-selected for presenting Fedgchin et. al. ${ }^{11}$ - a study to evaluate esketamine potential eligibility to the topic. In the end, 14 articles nasal spray in TRD patients; Karakula-Juchnowicz were considered relevant for the systematic review.

et. al. ${ }^{12}$ - a study about probiotic supplementation in patients with MDD; Sakurai et. al. ${ }^{13}$ - a study about The articles included studies by Fabbri et. al. ${ }^{6}$ - a study prolonged use of riluzole in patients with TRD; Zhuo about potential new treatments for TRD; Griffiths et.al. ${ }^{5}$ - a et. al. ${ }^{4}$ - a study about ketamine's ability to reverse study about the evaluation of ketamine's antidepressant depression and synaptic loss; Earley et. al. ${ }^{14}$ - a study and adverse effects on TRD; Hudgens et. al. ${ }^{1}$ - a study about the effect of cariprazine associated with ADT in about the response of esketamine nasal spray in patients patients with MDD; Hobart et. al. ${ }^{15}$ - a study about the with TRD; Melo et. al. ${ }^{8}$ - a study about the possible inferiority efficacy and safety of brexpiprazole in MDD; Nelson

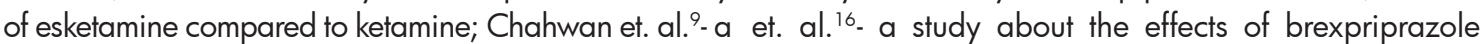
study about the probiotic's ability to act on depressive associated with ADT in patients with MDD. The main symptoms; Daly et.al. ${ }^{2}$ - a study about antidepressant use characteristics of the selected studies were summarized associated with esketamine nasal spray in patients with in Table 1.

Table 1. Summary of authors, journals, locations, objectives, methodologies, results and main findings of the studies included for analysis in the systematic review based on the PRISMA method.

\begin{tabular}{|c|c|c|c|c|c|}
\hline AUTHOR & JOURNAL & OBJECTIVE & METHOD & RESULTS & MAIN FINDINGS \\
\hline $\begin{array}{l}\text { Fabbri et. } \\
\text { al. }{ }^{6}\end{array}$ & $\begin{array}{l}\text { Progress in Neuro- } \\
\text { Psychopharmacology and } \\
\text { Biological Psychiatry }\end{array}$ & $\begin{array}{l}\text { To identify new possible } \\
\text { pharmacological options } \\
\text { for TRD. }\end{array}$ & $\begin{array}{l}\text { It was analy zed using a } \\
\text { hypergeomemetric test if targets of } \\
\text { already known genes were enriched } \\
\text { in genes associated with TRD. This } \\
\text { last one, after correcting the false } \\
\text { discovery rate, was compared with } \\
\text { genes associated with MDD that are } \\
\text { shown to be enriched. }\end{array}$ & $\begin{array}{l}542 \text { compounds enriched in genes } \\
\text { associated with TRD (FDR p } 00.05 \text { ) } \\
\text { were identified, out of a total of } 15,475 \text {. } \\
\text { Significant effects included drugs that } \\
\text { are already used today in TRD. }\end{array}$ & $\begin{array}{l}\text { This study suggests new } \\
\text { potential treatments for TRD. } \\
\text { However, the research results } \\
\text { are only exploratory, guiding the } \\
\text { identification of promising drugs } \\
\text { for this type of depression. }\end{array}$ \\
\hline $\begin{array}{l}\text { Griffiths } \\
\text { et.al. }^{.5}\end{array}$ & $\begin{array}{l}\text { Journal of Affective } \\
\text { Disordens Reports }\end{array}$ & $\begin{array}{l}\text { To e valuate the } \\
\text { antidepressant and adverse } \\
\text { effects of ketamine in } \\
\text { patients with TRD. }\end{array}$ & $\begin{array}{l}\text { Interpretative phenomenological } \\
\text { analysis (IPA) was used through } \\
\text { semi-structured interviews with 13 } \\
\text { patients with TRD. }\end{array}$ & $\begin{array}{l}\text { Effects such as initial dissociative } \\
\text { sensation, as well as improved } \\
\text { perception, followed by improvement } \\
\text { have been reported. With the associated } \\
\text { reduction of suicidal ideals, increased } \\
\text { motivation for daily activities, and } \\
\text { others, and improved mood. All effects } \\
\text { appeared as soon as the medication } \\
\text { was infused. }\end{array}$ & $\begin{array}{l}\text { Ketamine has beneficial effects on } \\
\text { patients with TRD and represents } \\
\text { hope for this group. }\end{array}$ \\
\hline $\begin{array}{l}\text { Hudgens } \\
\text { et. al. } 1\end{array}$ & $\begin{array}{l}\text { Journal of Affective } \\
\text { Disorders }\end{array}$ & $\begin{array}{l}\text { To assess the response of } \\
\text { patients with TRD to the use } \\
\text { of esketamine nasal spray } \\
\text { and an oral antidepressant. }\end{array}$ & $\begin{array}{l}\text { Evaluation of two multicenter, } \\
\text { randomized, double-blind, phase } \\
3 \text { studies using esketamine nasal } \\
\text { spray combined with an oral } \\
\text { antidepressant for four weeks } \\
\text { compared to the placebo group. }\end{array}$ & $\begin{array}{l}\text { Patients in the study who were treated } \\
\text { with esketamine nasal spray }+ \text { oral } \\
\text { antidepressant had a reduction higher } \\
\text { than or equal to } 50 \% \text { in MADRS } \\
\text { compared to the placebo group. }\end{array}$ & $\begin{array}{l}\text { The use of esketamine nasal } \\
\text { spray associated with an oral } \\
\text { antidepressant has significantly } \\
\text { improved both the frequency and } \\
\text { severity of symptoms in patients } \\
\text { with TRD. }\end{array}$ \\
\hline $\begin{array}{l}\text { Correia-Melo } \\
\text { et. al. }{ }^{8}\end{array}$ & $\begin{array}{l}\text { Journal of Affective } \\
\text { Disorders }\end{array}$ & $\begin{array}{l}\text { To test whether esketamine } \\
\text { is not inferior to ketamine } \\
\text { in terms of rapid induction } \\
\text { of remission of depressive } \\
\text { symptoms after a single } \\
\text { intravenous dose in patients } \\
\text { with TRD. }\end{array}$ & $\begin{array}{l}\text { A randomized, double-blind, active- } \\
\text { controlled, bicentre, non-inferiority } \\
\text { clinical trial with two parallel } \\
\text { groups. Participants in these groups } \\
\text { (one of ketamine }-0.5 \mathrm{mg} / \mathrm{kg} \text { and } \\
\text { one of esketamine }-0.25 \mathrm{mg} / \mathrm{kg} \text { ). }\end{array}$ & $\begin{array}{l}\text { Esketamine was not inferior to ketamine, } \\
\text { analyzing the remission at } 24 \text { hrs and } \\
72 \mathrm{hrs} \text {. However, in seven days, the } \\
\text { remission rate in the ketamine group was } \\
\text { higher. Regarding dissociative symptoms } \\
\text { during infusion, there was no significant } \\
\text { difference in the mean CADSS scores } \\
\text { between ketamine and esketamine. }\end{array}$ & $\begin{array}{l}\text { Esketamine was not inferior to } \\
\text { ketamine for TRD } 24 \text { hours after } \\
\text { intravenous administration. Both } \\
\text { drugs caused improvement in } \\
\text { depressive symptoms, with similar } \\
\text { mild and self-limited adverse effects. } \\
\text { Ketamine shows a tendency to have } \\
\text { a longer-lasting antidepressant } \\
\text { effect compared to esketamine, } \\
\text { but the difference has not reached } \\
\text { statistical significance and should } \\
\text { be evaluated in future studies. }\end{array}$ \\
\hline $\begin{array}{l}\text { Chahwan } \\
\text { et. al. } 9\end{array}$ & $\begin{array}{l}\text { Journal of Affective } \\
\text { Disordens }\end{array}$ & $\begin{array}{l}\text { To determine whether taking } \\
\text { a probiotic supplement } \\
\text { for eight weeks led to a } \\
\text { reduction in depressive } \\
\text { symptoms and to investigate } \\
\text { any potential effects of it on } \\
\text { cognitive reactivity to sad } \\
\text { mood. }\end{array}$ & $\begin{array}{l}\text { A randomized clinical trial using } \\
\text { probiotics for eight weeks in } \\
\text { patients from an initial triple-blind, } \\
\text { placebo-controlled study in which } \\
71 \text { depressive participants were } \\
\text { recruited using the Beck depression } \\
\text { inventory and } 20 \text { non-depressed } \\
\text { people for the control group. }\end{array}$ & $\begin{array}{l}\text { Both the placebo group and those using } \\
\text { the probiotic showed improvement in } \\
\text { symptoms, suggesting non-specific } \\
\text { therapeutic eftects associated with } \\
\text { weekly monitoring visits. However, } \\
\text { participants in the probiotic group } \\
\text { showed a higher significant reduction } \\
\text { in cognitive reactivity compared to } \\
\text { the placebo group, particularly in the } \\
\text { subgroup of mild/moderate depression. }\end{array}$ & $\begin{array}{l}\text { The use of probiotics can exert } \\
\text { changes in the cognitive patterns } \\
\text { that contribute to depression. The } \\
\text { routine used in the preparation and } \\
\text { daily consumption of the probiotic, } \\
\text { to seek and improve depressive } \\
\text { symptoms, had positive results in } \\
\text { mood, regardless of the use of the } \\
\text { probiotic or placebo. }\end{array}$ \\
\hline Daly et.al. ${ }^{2}$ & JAMA Psychiatry & $\begin{array}{l}\text { To evaluate the response of } \\
\text { patients with TRD to the use } \\
\text { of esketamine nasal spray } \\
\text { and an oral antidepressant. }\end{array}$ & $\begin{array}{l}\text { A randomized double-blind clinical } \\
\text { trial. } 455 \text { individuals received } \\
\text { treatment with esketamine nasal } \\
\text { spray and an oral antidepressant. } \\
\text { After } 16 \text { weeks of treatment, } 297 \\
\text { patients showed remission or a } \\
\text { stable response, participating in the } \\
\text { phase of random drug withdrawal. }\end{array}$ & $\begin{array}{l}\text { Of the } 297 \text { adults who entered the } \\
\text { maintenance phase, } 176 \text { achieved } \\
\text { stable remission, with } 24 \text { individuals in } \\
\text { the esketamine and oral antidepressant } \\
\text { group, and } 39 \text { in the placeboo group } \\
\text { relapsing. Of the } 121 \text { patients who } \\
\text { entered in a stable response, } 16 \text { in the } \\
\text { esketamine group and } 34 \text { in the placebo } \\
\text { group experienced relapse. Treatment } \\
\text { with esketamine nasal spray reduced } \\
\text { the risk of recurrence by } 51 \% \text { in patients } \\
\text { who obtained a stable remission and } \\
70 \% \text { in patients who obtained a stable } \\
\text { response. }\end{array}$ & $\begin{array}{l}\text { The association between } \\
\text { esketamine nasal spray and an } \\
\text { oral antidepressant had shown } \\
\text { to be superior and with a lower } \\
\text { relapse rate in the treatment of } \\
\text { patients with TRD. }\end{array}$ \\
\hline Costi et. al. ${ }^{10}$ & $\begin{array}{l}\text { Neuropsycho } \\
\text { pharmacology; }\end{array}$ & $\begin{array}{l}\text { To analyze whether, after } \\
\text { ketamine interruptions, } \\
\text { participants randomized to } \\
\text { lithium compared to placebo } \\
\text { had less severe depression } \\
\text { in two weeks. }\end{array}$ & $\begin{array}{l}\text { Eligible participants after the first } \\
\text { infusion of ketamine (IV) } 0.5 \mathrm{mg} / \\
\mathrm{kg} \text { with antidepressant response } \\
\text { improvement equal to or greater } \\
\text { than } 25 \% \text { in the MADRS scale score } \\
\text { were randomized in double-blind } \\
\text { conditions to lithium or placebo. }\end{array}$ & $\begin{array}{l}\text { Of the } 77 \text { participants assessed for } \\
\text { eligibility, } 42 \text { with TRD met the inclusion } \\
\text { criteria and received the test infusion } \\
\text { with ketamine (IV), } 35 \text { participants who } \\
\text { showed a response after } 24 \text { hours of the } \\
\text { infusion were randomized and entered } \\
\text { the double-blind lithium/placebo study. } \\
\text { Of these, } 34 \text { continued in the study } \\
\text { and were exposed to at least one dose } \\
\text { of lithium or placebo, which did not } \\
\text { differ in the continuation of the acute } \\
\text { antidepressant response to ketamine. }\end{array}$ & $\begin{array}{l}\text { Need for further studies to identify } \\
\text { an effective strategy to prevent } \\
\text { relapse of depression after an acute } \\
\text { course of ketamine treatment. }\end{array}$ \\
\hline
\end{tabular}


continuation table 1

\begin{tabular}{|c|c|c|c|c|c|}
\hline $\begin{array}{l}\text { Fedgchin et. } \\
\text { al. }{ }^{\prime}\end{array}$ & $\begin{array}{l}\text { International Journal of } \\
\text { Neuropsychopharmacology }\end{array}$ & $\begin{array}{l}\text { To evaluate the safety and } \\
\text { efficacy of the esketamine } \\
\text { nasal spray associated with } \\
\text { an oral antidepressant in } \\
\text { patients with TRD. }\end{array}$ & 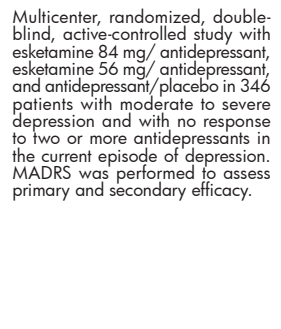 & 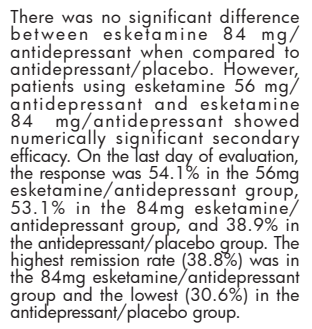 & $\begin{array}{l}\text { Esketamine proved to be safe and } \\
\text { tolerable in the short term, with } \\
\text { no significant changes in these } \\
\text { characteristics between doses. }\end{array}$ \\
\hline $\begin{array}{l}\text { Karakula- } \\
\text { Juchnowicz } \\
\text { et al. }{ }^{12}\end{array}$ & Nutrition Journal & $\begin{array}{l}\text { To demonstrate the effect } \\
\text { of interventions on the gut- } \\
\text { brain-microbiota axis in } \\
\text { patients with MDD. }\end{array}$ & $\begin{array}{l}\text { A randomized, 12-week, double- } \\
\text { blind, placebo-controlled study with } \\
\text { the aim of analyzing the effect of } \\
\text { probiotic supplementaion on the } \\
\text { mental status of patients with MDD } \\
\text { using a gluten-free and a non-gluten- } \\
\text { free diet. }\end{array}$ & $\begin{array}{l}\text { Proof of concept study. The use of } \\
\text { probiotits associated with a gluten- } \\
\text { rree diet can alter the mitrobiota-gut } \\
\text { brain axis, which is connected to the } \\
\text { pathophysiology of depression. }\end{array}$ & $\begin{array}{l}\text { The microbiota influences the CNS. } \\
\text { Therefore, the association of the } \\
\text { probibotic with the glutentree diet } \\
\text { inhibits the ithflammmatory cascaded } \\
\text { of the pathophysiology of MDD, } \\
\text { improving the psychiatric symptoms } \\
\text { that are connected to the intestinal } \\
\text { barrier. }\end{array}$ \\
\hline $\begin{array}{l}\text { Sakurai et. } \\
\text { al. } .^{13}\end{array}$ & $\begin{array}{l}\text { Journal of Affective } \\
\text { Disorders }\end{array}$ & $\begin{array}{l}\text { To evaluate the long-term } \\
\text { use of riluzole in patients } \\
\text { with TRD. }\end{array}$ & $\begin{array}{l}\text { 12.week open-label extension phase } \\
\text { of a randomized doubleb-bind, } \\
\text { placebo-controlled study in } 66 \\
\text { patients with TrD recesving riluzole. } \\
\text { sing MADRS for evaluation. }\end{array}$ & 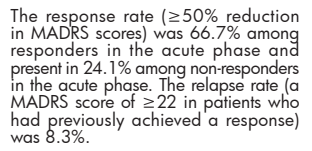 & $\begin{array}{l}\text { Riluzole showed good long-term } \\
\text { tolerability and may be beneficial } \\
\text { for some patients with TRD, } \\
\text { justifying a further evaluation. }\end{array}$ \\
\hline Zhuo et al. ${ }^{4}$ & Brain and Behavior & 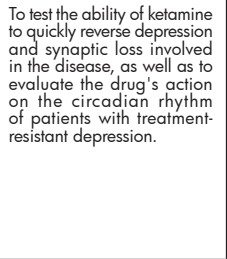 & 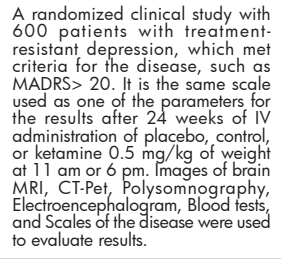 & 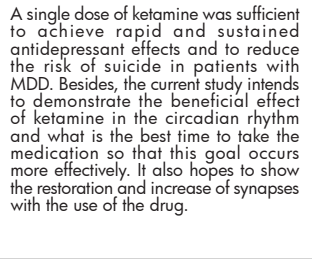 & $\begin{array}{l}\text { As it is a pilot clinical study, it } \\
\text { offers limitations which cannot } \\
\text { be compared to the revolutionary } \\
\text { scope of the discoveries about the } \\
\text { mechanisms of the effectiveness } \\
\text { of ketamine in the treatment for } \\
\text { resistant depression. }\end{array}$ \\
\hline $\begin{array}{l}\text { Earley et. } \\
\text { al.144 }\end{array}$ & $\begin{array}{l}\text { Psychopharmacology } \\
\text { Bulletin }\end{array}$ & 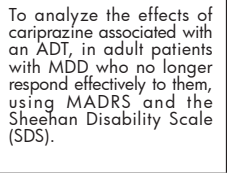 & 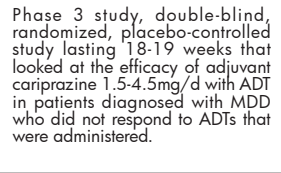 & 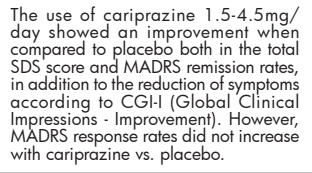 & $\begin{array}{l}\text { Associating cariprazine with ADT, } \\
\text { in adults with MDD who had an } \\
\text { inadequate response to ADT, did } \\
\text { not show a statistically significant } \\
\text { improvement while compared to } \\
\text { the use of placebos. However, the } \\
\text { use of adjuvant cariprazine has } \\
\text { shown a reduction in the symptoms } \\
\text { of MDD. }\end{array}$ \\
\hline $\begin{array}{l}\text { Hobart et } \\
\text { al. }{ }^{15}\end{array}$ & $\begin{array}{l}\text { The Journal of Clinical } \\
\text { Psychiatry }\end{array}$ & $\begin{array}{l}\text { To demonstrate the efficacy } \\
\text { of brexpiprazole } 2 \mathrm{mg} / \text { day } \\
\text { in combination with ADT in } \\
\text { patients with MDD. }\end{array}$ & $\begin{array}{l}\text { A randomized, placebo-controlled, } \\
\text { dobble-blind study in which patients } \\
\text { with inadequate response to ADT } \\
\text { were selected. Brexpiprazole } 2 \\
\text { mg/day was used and evaluated } \\
\text { by MADRS. }\end{array}$ & 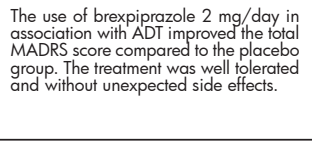 & $\begin{array}{l}\text { This study showed evidence that } \\
\text { brexpiprazole is effective and has } \\
\text { good tolerability as an adjunctive } \\
\text { treatment in MDD. The drug } \\
\text { showed advantages over placebo } \\
\text { mainly in patients with anxious } \\
\text { distress. }\end{array}$ \\
\hline $\begin{array}{l}\text { Nelson et. } \\
\text { al. } 16\end{array}$ & $\begin{array}{l}\text { Journal of Affective } \\
\text { Disorders }\end{array}$ & $\begin{array}{l}\text { To observe the effects of } \\
\text { brexpriprazale associated } \\
\text { with ADT on the main } \\
\text { symptoms of MDDD that were } \\
\text { defined using MARRS iterems. }\end{array}$ & $\begin{array}{l}\text { Post hoc analysis study for six } \\
\text { weeks, randomized, double-blind, } \\
\text { and placebo-controlled from two } \\
\text { similarly designed Phase } 3 \text { studies. } \\
\text { In the two studies, } 980 \text { patients } \\
\text { were analyzed, between } 18.65 \\
\text { years, that met the desired criteria. } \\
\text { During the study phase, participants } \\
\text { received ADT along with single- } \\
\text { blind placebos. }\end{array}$ & 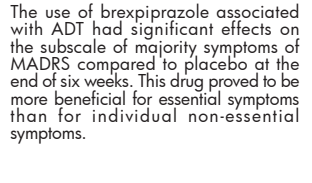 & $\begin{array}{l}\text { Associating brexpiprazole with ADT } \\
\text { showed a significant improvement } \\
\text { in the main symptoms in MDD. The } \\
\text { drug has been shown to exert its } \\
\text { effects on MDD, treating the main } \\
\text { symptoms of the disease. }\end{array}$ \\
\hline
\end{tabular}

Evaluation of the methodological quality of the included Barrier were seen as new viable treatments in addition studies to the usual therapy. Regarding TRD, it is a pathology classified from the therapeutic failure of at least two or

The most common methodological deficiencies in all three trials with antidepressants of adequate dose and studies arose from insufficient reporting: samples, duration. Thus, the new medications investigated for the scenarios and recruitment procedures were often not treatment of TRD were nasal and IV esketamine and, fully described. IV ketamine, riluzole, and cariprazine, drugs with the potential to aid in TRD (Figure 2).

\section{Mental health interventions}

Ten studies reported the urgent need to implement Discussion interventions related to new pharmacological therapeutic approaches for depressive disorders. Four studies Patients diagnosed with MDD may not respond or poorly demonstrate the need for interventions for organizational respond to the drugs used for this pathology. ${ }^{5}$ When adjustments through new pharmacological therapeutic this happens, other therapeutic strategies should be approaches for depressive disorders in the last four years. considered as a change from the current antidepressant or association with a second pharmacological agent. ${ }^{16}$ MDD is a complex, disabling mental illness and a Given this, there was a need for studies with new highly prevalent health problem worldwide. Therefore, agents, or the reuse of agents used therapeutically in brexpripazole and the probiotic Winclove's Ecologic ${ }^{\circledR}$ other clinical conditions, for depression. 


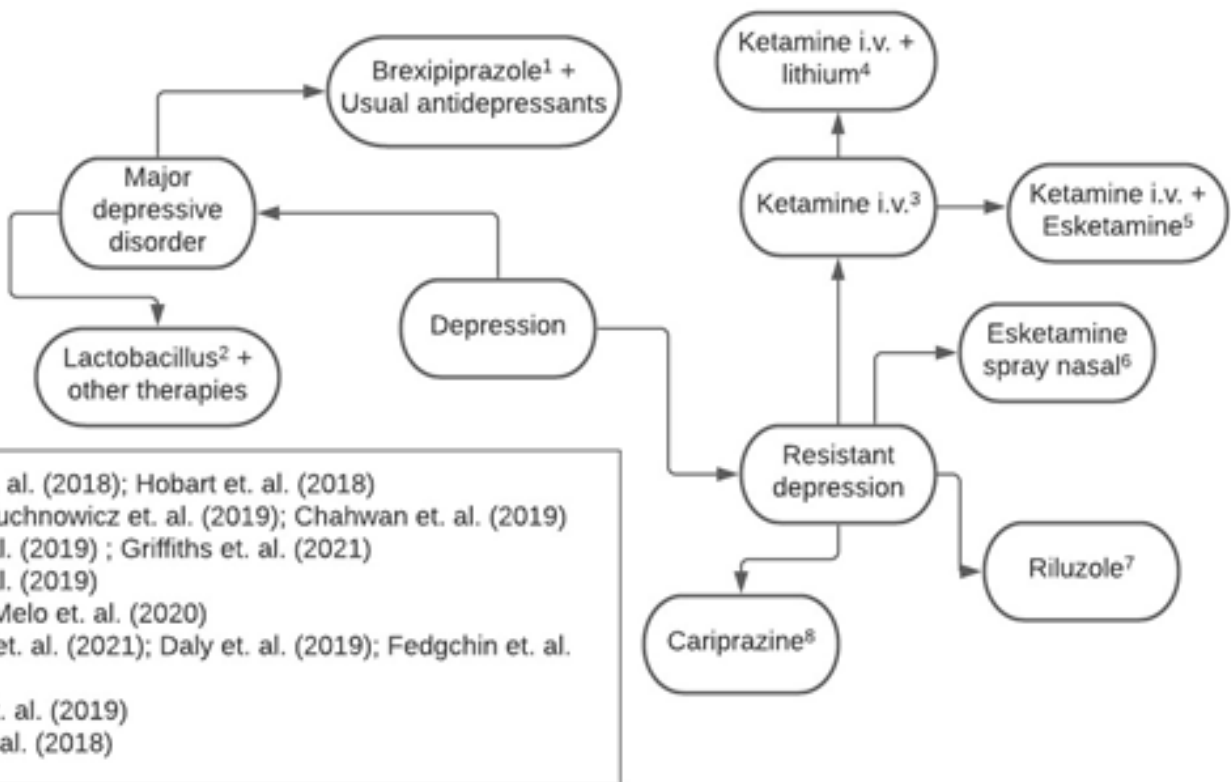

Figure 2. Conceptual map of the depressive disorders and drugs studied.

\section{Major Depressive Disorder (MDD)}

Brexpiprazole is a drug in the class of atypical antipsychotics that acts as a modulator of serotonindopamine activity, and that showed efficacy in the adjunctive treatment of MDD when in combination with antidepressants of different classes, in those patients who responded inadequately to ADT. ${ }^{15}$ Brexpiprazole $1 \mathrm{mg} /$ day, when associated with ADT for six weeks, showed a significant improvement in the MontgomeryAsberg Depression Rating Scale (MADRS) score, positively impacting the symptoms of apparent and reported sadness, internal tension, tiredness, inability to feel, and thoughts pessimists. ${ }^{16}$ The intestinal microbiota and its role in the gut-brain axis have been widely studied for several psychiatric pathologies including MDD. The main factors that generate the appearance of this depressive disorder are related to the inflammatoryimmune imbalance, and the modulation of this axis can be a promising therapeutic target for mental health. ${ }^{12}$ The use for eight weeks of the probiotic Winclove's Ecologic $($ Barrier, which is composed of nine bacterial strains: Bifidobacterium bifidum W23, Bifidobacterium lactis W51, Bifidobacterium lactis W52, L. acidophilus W37, Lactobacillus brevis W63, Lactobacillus casei W56, Lactobacillus salivarius W24, Lactococcus lactis W19 e Lactococcus lactis W58, was used as a treatment in mild to moderate MDD. This medication in monotherapy was not effective in reducing depressive symptoms. However, when associated with Cognitive Behavioral Therapy, it can make changes in the patterns of cognitive reactivity concerning the sad mood associated with depression. Therefore, it can be effective when used to complement and potentiate the symptoms effects of other treatments for depressive disorders. ${ }^{9}$

\section{Treatment Resistant Depression (TRD)}

Ketamine is a dissociative anesthetic that, in recent studies, is promising in the treatment of TRD. This drug represents new hope for those who, until then, have not responded with the combination of two or more antidepressants. ${ }^{4}$ Esketamine, the $\mathrm{S}$ enantiomer of ketamine, is an antagonist of the $\mathrm{N}$-methyl-d-aspartate (NMDA) receptor, and was recently approved by the Food and Drug Administration (FDA), in the form of a nasal spray, as pharmacological therapy in TRD. ${ }^{1,2,5}$

The choice of the ketamine $S$ enantiomer concerning $R$ is because it has greater affinity for the NMDA receptor than this one and, therefore, is considered more potent. The increase in the levels of glutamate in the synaptic cleft, provided by ketamine, consequently increases the number of synapses, which are reduced in depression. Such action of ketamine through the glutamatergic pathway is already pointed out as well established by the most recent studies, representing one of the mechanisms responsible for the quick antidepressant responses of the drug, since such action reverses the chronic loss of synapses that occurs in the disease. ${ }^{4,6}$

One study noted the change in MADRS scores in patients who had TRD. These patients started using a nasal spray containing $28 \mathrm{mg}$ of esketamine, administered 
twice a week, associated with the daily use of a new oral antidepressant that had not yet been used and that was one of the options of choice: duloxetine, sertraline, escitalopram or venlafaxine from prolonged action, and were compared with the placebo group that received placebo nasal spray and oral antidepressant. There was a significant improvement with the use of esketamine nasal spray, defined as a reduction higher than or equal to $50 \%$, or a reduction of 10 points, in MARDS, influencing both the severity of symptoms and their frequency. ${ }^{1,2}$

The adverse effects of pharmacological therapy were not significant and some patients experienced vertigo, headache, and dissociation as the most common changes. ${ }^{2,11}$ Although pharmacological therapy with esketamine nasal spray has shown beneficial results in the short term, its long-term effects are still unclear, and it is necessary to evaluate the efficacy of the drug in this context. $^{2}$ Esketamine was also studied in its IV form to compare its effectiveness with that of IV ketamine. In this study, the rate of remission of depressive symptoms in 24 hours of IV esketamine $0.25 \mathrm{mg} / \mathrm{kg}$ was $24.1 \%$ and

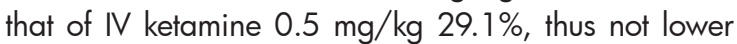
than ketamine and presenting both efficacy, tolerability, and safety. ${ }^{8}$

A phenomenological analysis was done with 13 patients with TRD who used IV ketamine, in an individual dose calculated according to height and weight. The doses administered ranged from $25 \mathrm{mg} / 40 \mathrm{ml}$ to 75 $\mathrm{mg} / 40 \mathrm{ml}$, all infused over 40 minutes, during three to 112 sessions. Interviews were conducted with these patients to assess the effects of the medication. For many of them, feelings such as "happy and laughing", "more willing to do activities", "greater socialization and communication with others", "feeling normal", "with positive thoughts" and "reduced suicidal ideation" were reported. ${ }^{5}$ Ketamine emerges as an effective therapy and able to work in different neurobiological pathways to provide its antidepressant actions. The drug can work in the circadian cycle, prolonging REM sleep time and increasing levels of brain-derived neurotrophic factor (BDNF) responsible for regulating slow-wave sleep. Thus, being able to redefine the changes in circadian rhythm caused by depression and improve synaptic plasticity is also affected by the disease. ${ }^{4,6}$ The action of ketamine in modulating inflammation and the immune system as an inhibitor of glycogen synthase kinase 3 beta (GSK3B) that modulates the activity of proteins responsible for mood regulation, also seems to be responsible for the rapid antidepressant effects of ketamine. ${ }^{6}$ Lithium, which is also an inhibitor of (GSK3), was the target of a randomized double-blind study that aimed to assess whether this drug was able to prolong the antidepressant effects of ketamine. The participants received IV ketamine and, then, associated with lithium 600 to $1200 \mathrm{mg} /$ day orally or with placebo for a week, and finally maintained with only lithium or placebo. However, no significant difference was seen between the groups. The addition of lithium did not, therefore, appear to have led to a reduction in MADRS scores compared to treatment with ketamine alone. ${ }^{10}$

In addition to ketamines, other drugs are targets for studies for patients with TRD and patients with inadequate response to ADT. Studies conducted with riluzole and cariprazine in these patients used MADRS to assess primary efficacy. The mechanism of action of riluzole is believed to be the inhibition of presynaptic release of glutamate through the inactivation of voltage-gated sodium channels in glutamatergic nerve terminals, it is a drug used to treat Amyotrophic Lateral Sclerosis (ALS) and has been evaluated as long-term therapy in patients with TRD. Riluzole showed positive results, as it can promote a reduction higher than or equal to $50 \%$ in MADRS, despite not showing great differences concerning the placebo in terms of efficacy for the treatment of patients with TRD. The study realized with cariprazine, an atypical antipsychotic whose main mechanism of action is the partial agonist of dopamine D2 and D3 receptors, in patients with inadequate response to the usual treatment with antidepressants, did not show any significant changes in MADRS or a considerable decrease in depressive symptoms when faced with placebo. Consequently, further studies should be carried out to better understand these drugs in the treatment of depression. ${ }^{13,14}$

\section{Conclusion}

Knowing that $20-30 \%$ of patients with MDD develop TRD ${ }^{6}$, the new therapies under study appear to improve the approach of these patients and prevent disease progression.

According to this systematic review, the use of brexpiprazole associated with antidepressants of different classes, as well as the use of Winclove's Ecologic $(R$ Barrier-type lactobacilli for eight weeks, showed short-term efficacy in the treatment of MDD. On the other hand, pharmacological options, such as ketamine, esketamine, riluzole, and cariprazine, appear as new possibilities for those who until then have not obtained remission of the depressive disorder with the use of more than two antidepressants.

As assessed by Griffiths et. al. ${ }^{5}$ and Fabbri et. al. ${ }^{6}$, although the new pharmacological options addressed 
in our study have shown efficacy in the treatment of depressive disorders, we realize that there are still gaps in both the knowledge of the action of drugs at the neurobiological level associated with the neurophysiology of the disease and the action of these drugs over the long term.

Taysa Leite de Aquino

https://orcid.org/0000-0003-1161-6460

Jaiany Rodrigues Libório

https://orcid.org/0000-0002-6757-2631

Ana Luiza Menezes Santana Bezerra

https://orcid.org/0000-0002-2416-4283

Giovana Macêdo Egídio Cavalcante

https://orcid.org/0000-0002-3095-9066

Dara Fernanda Brito Duarte

https://orcid.org/0000-0002-2416-4283

Ana Luíza de Aguiar Rocha Martin

https://orcid.org/0000-0001-5004-5117

Juliane dos Anjos de Paula

https://orcid.org/0000-0002-2992-988X

Modesto Leite Rolim Neto

https://orcid.org/0000-0001-9379-2120

\section{Acknowledgements}

The authors would like to thank the Research Group: Suicidology - Universidade Federal do Ceará (UFC) and Brazilian National Council for Scientific and Technological Development (CNPq) - institution linked to the Brazilian Department of Science, Technology and Scientific Writing Lab, Medicine School Universidade Federal of Cariri (UFCA).

\section{Funding}

The Research Group: Suicidology - Universidade Federal do Ceará (UFC) and Brazilian National Council for Scientific and Technological Development (CNPq) - institution linked to the Brazilian Department of Science, Technology and Innovation to encourage research in Brazil.

\section{Conflict of interests}

The authors declare that they have no competing interests.

\section{Ethical Statement}

We declare that there is no ethical conflict.

All authors agree to send the manuscript for publication.

\section{References}

1. Hudgens S, Floden L, Blackowicz M, Jamieson C, Popova V, Fedgchin M, . . . Singh J. Meaningful
Change in Depression Symptoms Assessed with the Patient Health Questionnaire (PHQ-9) and Montgomery-Åsberg Depression Rating Scale (MADRS) Among Patients with Treatment Resistant Depression in Two, Randomized, Double-blind, Active-controlled Trials of Esketamine Nasal Spray Combined With a New Oral Antidepressant. J Affect Disord 2021;281:767-775 Doi:10.1016/i. jad.2020.11.066

2. Daly EJ, Trivedi MH, Janik A, Li H, Zhang Y, Li X, ... Singh JB. Efficacy of Esketamine Nasal Spray Plus Oral Antidepressant Treatment for Relapse Prevention in Patients With Treatment-Resistant Depression: A Randomized Clinical Trial. JAMA Psychiatry 2019;76(9):893-903 Doi:10.1001/ jamapsychiatry.2019.1189

3. Organization WH. Depression [Internet]. Available from: https://www.who.int/healthtopics/depression\#tab=tab_1.

4. Zhuo $C$, Tian $H$, Li G, Chen M, Jiang $D$, Lin $X$, ... Wang $W$. Effects of ketamine on circadian rhythm and synaptic homeostasis in patients with treatment-resistant depression: A protocol for mechanistic studies of its rapid and sustained antidepressant actions in humans. Brain Behav 2019;9(1 1):e01423 Doi:10.1002/brb3.1423

5. Griffiths C, Walker K, Reid I, da Silva KM and O'Neill-Kerr A. A qualitative study of patients' experience of ketamine treatment for depression: The 'Ketamine and me' project. Journal of Affective Disorders Reports 2021;4:100079 Doi:https:// doi.org/10.1016/i.jadr.2021.100079

6. Fabbri C, Kasper S, Zohar J, Souery D, Montgomery $S$, Albani $D, \ldots$ Serretti A. Drug repositioning for treatment-resistant depression: Hypotheses from a pharmacogenomicstudy. Prog Neuropsychopharmacol Biol Psychiatry 2021;104:110050 Doi:10.1016/i. pnpbp.2020.110050

7. WebPlotDigitizer. Web based tool to extract data from plots, images, and maps [Internet]. 2021 Available from: https://apps.automeris.io/wpd/.

8. Correia-Melo FS, Leal GC, Vieira F, Jesus-Nunes AP, Mello RP, Magnavita G, ... Quarantini LC. Efficacy and safety of adjunctive therapy using esketamine or racemic ketamine for adult treatment-resistant depression: A randomized, double-blind, noninferiority study. J Affect Disord 2020;264:527534 Doi:10.1016/i.jad.2019.11.086

9. Chahwan B, Kwan S, Isik A, van Hemert S, Burke C and Roberts L. Gut feelings: A randomised, triple-blind, placebo-controlled trial of probiotics for depressive symptoms. I Affect Disord 2019;253:317-326 Doi:10.1016/i. jad.2019.04.097

10. Costi S, Soleimani L, Glasgow A, Brallier J, Spivack 
J, Schwartz J, ... Murrough JW. Lithium continuation therapy following ketamine in patients with treatment resistant unipolar depression: a randomized controlled trial. Neuropsychopharmacology 2019;44(10): 1812-1819 Doi:10.1038/s41386019-0365-0

11. Fedgchin M, Trivedi M, Daly EJ, Melkote R, Lane R, $\operatorname{Lim} P, \ldots$ Singh JB. Efficacy and Safety of FixedDose Esketamine Nasal Spray Combined With a New Oral Antidepressant in Treatment-Resistant Depression: Results of a Randomized, DoubleBlind, Active-Controlled Study (TRANSFORM-1). Int J Neuropsychopharmacol 2019;22(10):616-630 Doi: 10.1093/ijnp/pyz039

12. Karakula-Juchnowicz H, Rog J, Juchnowicz D, Łoniewski I, Skonieczna-Żydecka K, Krukow P, . . . Kaczmarczyk M. The study evaluating the effect of probiotic supplementation on the mental status, inflammation, and intestinal barrier in major depressive disorder patients using gluten-free or gluten-containing diet (SANGUT study): a 12-week, randomized, double-blind, and placebo-controlled clinical study protocol. Nutr J 2019;18(1):50 Doi: 10.1186/s12937-019-0475-x
13. Sakurai H, Dording C, Yeung A, Foster S, Jain F, Chang $T$, . . . Cusin $C$. Longer-term open-label study of adjunctive riluzole in treatment-resistant depression. J Affect Disord 2019;258:102-108 Doi:10.1016/i.jad.2019.06.065

14. Earley WR, Guo H, Németh G, Harsányi J and Thase ME. Cariprazine Augmentation to Antidepressant Therapy in Major Depressive Disorder: Results of a Randomized, Double-Blind, Placebo-Controlled Trial. Psychopharmacol Bull 2018;48(4):62-80

15. Hobart $M$, Skuban $A$, Zhang $P$, Augustine C, Brewer C, Hefting N, . . . McQuade RD. A Randomized, Placebo-Controlled Study of the Efficacy and Safety of Fixed-Dose Brexpiprazole $2 \mathrm{mg} / \mathrm{d}$ as Adjunctive Treatment of Adults With Major Depressive Disorder. J Clin Psychiatry 2018;79(4):Doi:10.4088/JCP.17m 12058

16. Nelson JC, Weiller E, Zhang P, Weiss C and Hobart M. Efficacy of adjunctive brexpiprazole on the core symptoms of major depressive disorder: A post hoc analysis of two pooled clinical studies. $J$ Affect Disord 2018;227:103-108 Doi:10.1016/i. jad.2017.09.054 